reducing the sense of vulnerability that patients have."

Yet, while US facilities appear to be moving toward the appointment of nocturnists as a solution to variations in care by time of day or day of week, the response in Canadian hospitals appears more piecemeal.

The Canadian Healthcare Association declined comment on the issue, so it is difficult to determine whether there are commonalities in the responses of Canadian hospitals. But it appears that hospitals are essentially being left to their own devices to find solutions and that most of their responses are based on some measure of shift work or differential pay for physicians willing to work nights or weekends.

In comparison with the US, "I don't think that after-hour coverage is as well funded in Canada," says Dr. David Wilton, president of the Canadian Society of Hospital Medicine and a hospitalist at the Vancouver General Hospital in British Columbia.

Rather than providing designated monies to bolster night staffing levels, governments typically suggest that hospitals and physician associations shift available resources around to accommodate the need, Wilton adds.

That's certainly the case in BC, where a spokesperson for the BC Ministry of Health writes in an email that "with respect to our contracted arrangements for 24/7 care, such as Emergency Departments or Hospitalists, it is left to the physician group to weight time periods (night, weekends, holidays) as they deem best appropriate for care. It is our understanding that the rates we pay are sufficient to allow this flexibility."

But Wilton says that Canada's singlepayer health care system makes it more difficult to provide financial incentives. "It has to be a policy decision rather than a response to market force. So what we need to do is raise awareness amongst people in the administration."

Instead, most hospitals fiddle with some manner of shift work. At the Vancouver General, for example, almost all physicians must work one week of evenings (4 pm until midnight), followed by four weeks of day shifts. Medical issues that crop up after midnight are either handled by phone or by an overnight critical care outreach team "followed by the MRP [most responsible physician] as soon as possible."

"What we're seeing here is that groups are evolving out of necessity to incorporate nocturnist-type work into their general work rotation, but we're not incentivizing it," Wilton says. "You don't get fewer shifts because you're the evening person or more compensation because you're the evening person. You're sort of doing it because you're obligated to it as part of your clinical compliment."

Wilton adds that other jurisdictions have looked to such solutions as 24-hour in-house hospitalist coverage or province-wide on-call coverage programs. But the location and size of a hospital often limits its flexibility, he says.

Further complicating the matter are such issues as hospital teaching respon- sibilities; legal disputes over resident working hours and a general demand for shorter shifts.

The training issues can be thorny. "Given the fact that duty hours are changing, how do we adapt? How do we make sure we're training very competent physicians with this change," says Dr. Kevin Imrie, vicepresident, education, Royal College of Physicians and Surgeons of Canada, adding that the same services and staff aren't available at night so residents working night shifts may not get the same experience.

Imrie adds that "one of the things that's very, very clear is that as you restrict shift lengths, you are going to increase the potential risk of discontinuity of care." Some of that risk may be overcome by effective handovers during shift changes, which become increasingly important as hospitals develop more concrete programs to improve night and weekend care, he says.

Gruman forecasts that the change won't come easy. Developing a new framework will not be simple for hospitals because they are "big clunky machines" that don't like change, she says.

But it's important to view care variations by hour of day or day of week from a patient perspective, Gruman adds. "Your experience of being ill is a 24-hour experience. It doesn't just happen during business hours." - Erin Walkinshaw, Ottawa, Ont.

CMAJ 2011. DOI:10.1503/cmaj.109-3953

\title{
Highlights of CMA's 144th annual general meeting
}

\section{Health care funding model flawed, blue-ribbon CMA panel argues}

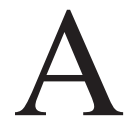
lternative models for health care financing, including "user fees, franchises and various insurance schemes" are needed if Canada's health care system is to avoid privatization, according to a Canadian Medical Association advisory panel struck to recommend means to improve governance of the health care system and to generate resources to ensure the system's sustainability.

The Report of the Advisory Panel on Resourcing Options for Sustainable Health Care in Canada, released at the CMA's annual general meeting in St. John's, Newfoundland and Labrador also called for increased provider competition and less micromanagement of the health system by government.

A discussion of a range of alternative ways of funding the system is impera- tive, the report states. "At present, apart from Medicare services, individuals either pay privately for all or a large part of supports across the continuum of care, or forgo them for cost reasons. This is equitable and also creates the wrong incentives, as individuals naturally turn first to the services for which they do not pay anything, even though other interventions might be faster, better for them and less costly to society as a whole."

More private delivery of health care services should occur within a framework 
that includes "continuing provision of medically necessary services at no cost to patients, competition based on standards of quality as well as price, a level regulatory playing field that applies to public, private and non-profit providers and ensures appropriate minimum standards, licensing and other protections; and transparent criteria for requests for proposals, determination of prices and the awarding of contracts," the report added.

Governments, meanwhile, should abandon the urge to micromanage the system and follow a "loose-tight" approach to governance, with "a tight focus on desired outcomes and performance standards but greater flexibility for those within the system to achieve desired outcomes," the report argued.

Other recommendations included:

- Adopt activity-based funding for hospitals, which provides payment on the basis of patient-related activities, rather than block funding.

- Update provincial fee schedules so that payment of physicians better reflects the resources used in providing services.

- Develop health quality councils with strong physician representation as a means to set expected outcomes and performance measures.

- Negotiate accountability agreements between physicians, health care organizations and governments.

- Work with provincial and territorial associations to contain pharmaceutical costs.

- Advocate for a rethinking of Canada's national electronic health information strategy and push for greater use of electronic records by physicians (www.cmaj.ca/lookup/doi /10.1503/cmaj.109-3976). — Lauren Vogel, CMAJ

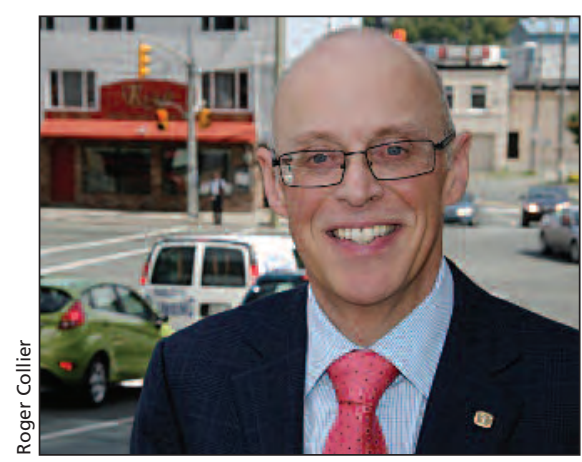

CMA President Dr. John Haggie

\section{Panel's recommendations could open privatization floodgates, delegates warn}

$\mathrm{T}$ oo broad. Open to misinterpretation. Soft on patient responsibility. The recommendations of the Canadian Medical Association's blue-ribbon advisory panel on health care transformation were met with an array of criticisms after being unveiled.

Delegates assailed the broad-stroke language of the panel's report, arguing that its recommendation that the private sector play a bigger role in the provision of publicly funded health services could be interpreted as "opening the floodgates to private, for-profit monetized health care in Canada" (www.cmaj.ca /lookup/doi/10.1503/cmaj.109-3979). — Lauren Vogel, CMAJ

\section{Federal government unveils patient-oriented research strategy}

$\mathrm{T}$ he fruits of medical research are often absent in clinical settings, a problem the Canadian government plans to address with a national patient-oriented strategy to "better integrate health research and health care," federal Minister of Health Leona Aglukkaq vowed Aug. 21.

"Today, a new patient-oriented research strategy is being launched that is designed to help provinces and territories meet the challenge of delivering highquality, cost-effective health care by ensuring that the right patient receives the right treatment at the right time," Aglukkaq said during an address to delegates at CMA's annual general meeting in St. John's. "Evidence-based research will help health care providers compare the outcomes of different treatment options for patients and determine the best course of action."

The gulf between the wet-bench and the bedside is a well-known problem in Canada, a country with strong basic medical research that too rarely results in actual benefits for patients (www.cmaj .ca/cgi/doi/10.1503/cmaj.109-3814).

Canada's new strategy proposes to roll all manner of research, from clinical trials to comparative outcomes research, under the rubric of one umbrella. It defines patient-oriented research as "continuum of research, from initial studies in humans to comparative effectiveness and outcomes research, and the integration of this research into the health care system and clinical practice" (www.cihr-irsc.gc.ca/e/44000.html).

The strategy's main objectives?

- "To create a collaborative, pan-Canadian process for identifying, establishing and addressing patient-oriented research priorities;

- To establish an integrated, leadingedge pan-Canadian clinical research infrastructure along the full continuum of patient-oriented research;

- To grow Canada's capacity to attract, train and mentor health professionals and health researchers, as well as to create sustainable career paths in patient-oriented research;

- To strengthen organizational, regulatory and financial support for clinical studies in Canada and enhance patient and clinician engagement in these studies; and

- To improve processes for the early identification of best practices, expedite their development and harmonization into guidelines for patient care and support their adoption by clinicians, caregivers and patients" (www.cmaj.ca/lookup/doi /10.1503/cmaj.109-3978). — Roger Collier, CMAJ

\section{Mediocrity has become the norm, Turnbull asserts in valedictory address}

I llnesses prolonged because of unaffordable medications. Operations cancelled because of hospital overcapacity. Debilitating pain because of delayed knee joint replacements. Millions of Canadians without family doctors. This is Canada's health care system. And it's a system Canadians can no longer take pride in, says outgoing CMA President Dr. Jeffrey Turnbull.

"We have seen a slow but steady decline in what we would all now agree is a deeply troubled health care system," Turnbull told delegates at the CMA's 144th annual general meeting in 
St. John's during his valedictory speech on Aug. 23. "To be clear, this pillar of Canadian society is eroding."

And it's only getting worse, said Turnbull, noting that Canada's health care system continues to fall down the ranks internationally in areas such as value for money spent and effectiveness. Turning things around, Turnbull suggested, will require tackling social inequalities, shifting focus from acute care to chronic illnesses and improving leadership in the medical profession.

Mediocrity has become the accepted norm, said Turnbull, and health care transformation is considered a mountain too big to climb. "Like you, like patients and other providers, I have been struck by this lack of leadership, coordinated management, accountability and responsibility, and, yes, we see needless waste. But I honestly believe that change is afoot."

That change, according to Turnbull, starts with the CMA's health care transformation initiative, as it contains many important principles, and even more importantly, offers proof that physicians and health care organizations across the nation can reach a consensus on what matters most.

One important change that should occur, said Turnbull, is a slowing of the increasing social inequity in Canada, which leads to health inequities and higher costs. A vital step in that direction is the need to offer basic levels of prescription drug coverage to citizens, including the poor, the mentally ill, the elderly, Aboriginal populations and other groups that are often neglected.

The current "mish-mash" of public and private financing for medication is unacceptable, said Turnbull. "Creating a national drug strategy or pharmacare plan and a similar vision for long-term care are the two key features to establishing the next generation of medicare."

The health care system must also shift from an "acute care paradigm" to a model focused on treating the chronically ill, Turnbull added.

This will require new management systems, partnerships, accountability structures and a team-based, patient-centred approach to meeting health needs in the home (www.cmaj.ca/lookup/doi /10.1503/cmaj.109-3982). - Roger Collier, CMAJ
Health care system needs new revenue streams, expert argues: To cover its costs, the Canadian health care system will need more revenues generated through user fees, tax increases or private financing, argued Mark Stabile, director of the School of Public Policy and Governance at the University of Toronto, during a special session of health care funding at CMA's annual general meeting (www.cmaj.ca/lookup/doi/10.1503/cmaj .109-3975). — Roger Collier, CMAJ

Pack pooches in the cargo hold: Stick Fido in cargo. Leave Fluffy with relatives. Put Rover in a kennel. Bring your pet anywhere you want when you go on vacation, as long as it's not the cabin of your plane, CMA delegates urged while passing a motion to recommend a ban on pets travelling inside passenger cabins (www.cmaj.ca/lookup/doi/10.1503/cmaj .109-3983). — Roger Collier, CMAJ

Brevity is the soul of advocacy, experts say: "Keep it simple, stupid." That's the advice a panel of experts gave delegates to CMA's annual general meeting during a strategic session on how to influence politicians, the media and patients to transform the health care system (www.cmaj.ca/lookup/doi/10.1503/cmaj .109-3984). — Lauren Vogel, CMAJ

CMA president-elect traverses wildernesses: Dr. Anna Reid felt committee-ed out after working in British Columbia, so she accepted a job in the Yukon Territory in search of the quiet life. That notion ended Aug. 23 when she was ratified as CMA president-elect (www.cmaj .ca/lookup/doi/10.1503/cmaj.109-3981). — Roger Collier, CMAJ

Bid to expand horizon of medical students fails: A motion to support the inclusion of global health training in the core curriculum of medical education was narrowly defeated by CMA delegates (www.cmaj.ca/lookup/doi/10.1503 /cmaj.109-3986). - Roger Collier, CMAJ

Ontario physicians get liability fee break: The Canadian Medical Protection Association will tap its pool of "excess" assets to substantially reduce medical liability fees for Ontario doctors in 2012 (www.cmaj.ca/lookup/doi/10.1503/cmaj .109-3991). — Lauren Vogel, CMAJ

Specialty training out-of-sync with job market: A national forum should be convened to align postgraduate training with the realities of the job market, as flatlining demand for once highly sought-after specialties is leaving an increasing number of new graduates without work to match their skills or pay down their debts, physicians argued (www.cmaj.ca/lookup/doi/10.1503/cmaj .109-3985). — Lauren Vogel, CMAJ

CMA urges prescription-only antibiotics for agricultural use: Antibiotics shouldn't be used in Canada's agricultural sector except by prescription from veterinarians, the nation's doctors say (www.cmaj.ca/lookup/doi/10.1503/cmaj .109-3989). — Lauren Vogel, CMAJ

Mobilize at government doorsteps, CMA's new president urges: CMA's challenge over the coming year will be to achieve "some tangible results" in the implementation of its health care transformation proposal, President Dr. John Haggie says. (www.cmaj.ca/lookup/doi /10.1503/cmaj.109-3987). — Roger Collier, CMAJ

Support urged for physicians who speak out on health care issues: Powerless, passed over and pushed out of the decision making of a system they once ruled. Physicians painted a bleak selfportrait of themselves as the exiled kings of Canada's health care system during discussions on physician advocacy and apathy (www.cmaj.ca/lookup /doi/10.1503/cmaj.109-3990). — Lauren Vogel, CMAJ

No user fees, but perhaps user fees: Facing somewhat of a firestorm of nationwide criticism, CMA stepped back from an advisory panel recommendation that Canada should consider the implementation of health care user fees, while simultaneously arguing that "all the options" should remain on the table, even those less politically expedient (www.cmaj.ca/lookup/doi/10.1503/cmaj .109-3988). — Lauren Vogel, CMAJ

CMAJ 2011. DOI:10.1503/cmaj.109-3977 